\title{
PERANAN INDUSTRI KECIL DALAM MENINGKATKAN PENDAPATAN MASYARAKAT Kasus Pada Industri Kerajinan Batik Kayu di Dusun Krebet, Sendangsari, Pajangan, Bantul
}

\author{
Josephine Wuri \\ Yuliana Rini Hardanti \\ Universitas Sanata Dharma Yogyakarta
}

\begin{abstract}
This research is intended to determine the most influencing variable towards the profit of craft men, and to identify the differences in profit based on production, marketing, and economic and social aspects. This research was conducted at the of batik kayu (batik motive painted on wood) industry located in Krebet, Pajangan, Bantul. Data employed in the study were primary data collected from the research location. The method of primary data collection was by questioner and direct interview to respondents. The Purposive Sampling Method was used in determining the samples, and the Multiple Linear Regression and Compare Means Test Method was used as the analysis method. The result of this research indicates that the value of production was the most significant variable that influenced the profit of craft men. Production aspect showed that there was a significant difference of profit means that based on the source of capital and the number of labor. Marketing aspect showed that there was not a significant difference of profit means on the craft men that do direct selling or selling through agent. There was not a significant difference of profit means between those who do and do not do advertising. Economic and social aspect showed that there was a significant difference of profit means based on craft men that have and do not have license.
\end{abstract}

Keywords: Profit, Small and Medium Enterprise, Multiple Linear Regression, Compare Means Test.

\section{PENDAHULUAN}

Dalam rangka meningkatkan kesejahteraan masyarakat, Usaha Kecil dan Menengah (UKM) memiliki peran yang sangat strategis mengingat berbagai potensi yang dimilikinya. Potensi tersebut antara lain mencakup jumlah dan penyebarannya, penyerapan tenaga kerja, penggunaan bahan baku lokal, keberadaannya di semua sektor ekonomi, dan ketahanannya terhadap krisis.

Pada saat usaha besar dan konglomerasi masih menata usahanya kembali atau merestrukturisasi usahanya, UKM justru terus berproduksi, bahkan sebagian mulai melakukan ekspansi. Selain itu, UKM memiliki potensi pasar yang tinggi mengingat kemampuan UKM berproduksi dengan biaya yang rendah, harga produk yang dihasilkan juga lebih rendah sehingga dapat terjangkau oleh golongan masyarakat berpenghasilan rendah. Akhir-akhir ini peran UKM diharapkan sebagai salah satu sumber peningkatan ekspor non migas. Dengan adanya potensi yang dimiliki UKM diharapkan dapat meningkatkan produktivitas masyarakat miskin untuk meningkatkan pendapatannya.

Pada tahun 2003 data BPS menunjukkan jumlah UKM sebesar 42,4 juta namun sebagian besar bergerak di sektor pertanian. Angka ini telah mengalami perkembangan dibandingkan tahun-tahun sebelumnya, tahun 2002 jumlah usaha kecil sebesar 41,3 juta unit, usaha menengah sebesar 61.052 unit dan usaha besar hanya sekitar 2.198 unit. Dari data tersebut terlihat bahwa jumlah unit industri kecil sebesar 99,8 \% dari total unit usaha (Dep. Kop. \& UKM, 2004). 
Dari segi penyerapan tenaga kerja, tahun 2003, sektor UKM mampu menyerap sebesar 79 juta orang dari seluruh tenaga kerja yang ada $(99,4 \%)$. Sektor yang paling banyak menyerap tenaga kerja adalah sektor pertanian yaitu sebesar $48,04 \%$.

\section{Tabel 1}

Jumlah Penyerapan Tenaga Kerja Usaha Kecil, Menengah dan Besar Menurut Sektor Ekonomi Tahun 2003

\begin{tabular}{|c|c|c|c|c|c|}
\hline \multirow[t]{2}{*}{ Sektor } & \multicolumn{5}{|c|}{ Skala Usaha } \\
\hline & Kecil & Menengah & UKM & Besar & Jumlah \\
\hline $\begin{array}{l}\text { Pertanian, Peternakan, } \\
\text { Kehutanan, dan } \\
\text { Perikanan }\end{array}$ & 37.165 .045 & 807.048 & 37.972 .093 & 44.726 & 38.016 .819 \\
\hline $\begin{array}{l}\text { Pertambangan dan } \\
\text { Penggalian }\end{array}$ & 599.465 & 253.734 & 853.199 & 25.484 & 878.683 \\
\hline Industri Pengolahan & 7.297 .941 & 3.624 .938 & 10.922 .879 & 239.580 & 11.162 .459 \\
\hline $\begin{array}{l}\text { Listrik, Gas, dan Air } \\
\text { Bersih }\end{array}$ & 6.382 & 87.629 & 94.011 & 9.603 & 103.614 \\
\hline Bangunan & 712.010 & 645.239 & 1.357 .249 & 14.022 & 1.371 .271 \\
\hline $\begin{array}{l}\text { Perdagangan, Hotel, dan } \\
\text { Restoran }\end{array}$ & 16.145 .340 & 1.450 .801 & & 27.637 & 17.623 .778 \\
\hline $\begin{array}{l}\text { Pengangkutan dan } \\
\text { Komunikasi }\end{array}$ & 3.728 .387 & 375.563 & 03.950 & 18.010 & 4.121 .960 \\
\hline $\begin{array}{l}\text { Keuangan, persewaan, } \\
\text { dan Jasa Perusahaan }\end{array}$ & 122.885 & 288.275 & 411.160 & 14.095 & 425.255 \\
\hline Jasa-Jasa & 4.504 .723 & 1.221 .388 & 5.726 .111 & 45.041 & 5.771 .152 \\
\hline Jumlah & 70.282 .178 & 8.754 .615 & 79.036 .793 & 438.198 & 79.474 .991 \\
\hline
\end{tabular}

Sumber: Dep. Koperasi \& UKM, 2004

Dalam menghadapi persaingan yang semakin ketat, karena semakin terbukanya pasar di dalam negeri, banyaknya barang dan jasa yang masuk dari luar negeri merupakan ancaman bagi UKM. Oleh karena itu, pembinaan dan pengembangan UKM merupakan kebutuhan yang sangat mendesak untuk mencegah semakin melonjaknya angka pengangguran. Dengan berkembangnya UKM diharapkan dapat meningkatkan pendapatan masyarakat, membuka kesempatan kerja, dan meningkatkan kemakmuran masyarakat secara keseluruhan dan akhirnya akan mengurangi tingkat kemiskinan di Indonesia.

Data mengenai UKM, khususnya sektor kerajinan di DIY menunjukkan bahwa jumlah unit usaha, tenaga kerja, dan nilai investasi industri kerajinan di Kabupaten Bantul paling tinggi dibandingkan kabupaten lainnya. Data tersebut menunjukkan bahwa Kabupaten Bantul memiliki potensi besar untuk mengembangkan usaha kerajinan di masa mendatang (Desembriarto, 2004). 
Tabel 2

Perkembangan Industri Kerajinan di DIY Tahun 2003

\begin{tabular}{lrrrrrr}
\hline \multicolumn{1}{c}{ Wilayah } & \multicolumn{2}{c}{$\begin{array}{c}\text { Unit Usaha } \\
\text { (Unit) }\end{array}$} & \multicolumn{2}{c}{$\begin{array}{c}\text { Tenaga Kerja } \\
\text { (orang) }\end{array}$} & \multicolumn{3}{c}{$\begin{array}{c}\text { Nilai Investasi } \\
\text { (Juta Rp) }\end{array}$} \\
\cline { 2 - 7 } & Jumlah & $\%$ & Jumlah & $\%$ & Jumlah & $\%$ \\
\hline Kota Yogyakarta & 883 & 3,9 & 4.115 & 6,8 & 28.470 & 26,9 \\
Bantul & 6.151 & 27,2 & 18.830 & 31,0 & 36.310 & 34,3 \\
Kulon Progo & 5.404 & 23,9 & 15.865 & 26,1 & 16.529 & 15,6 \\
Gunung Kidul & 4.713 & 20,8 & 11.979 & 19,7 & 11.814 & 11,2 \\
Sleman & 5.462 & 24,1 & 9.866 & 16,2 & 12.750 & 12,0 \\
Total DIY & 22.163 & 100 & 60.655 & 100 & 105.873 & 100 \\
\hline
\end{tabular}

Sumber: Disperindagkop DIY, 2004

Data pada tabel 2 di atas menunjukkan bahwa usaha kerajinan di Kabupaten Bantul menduduki urutan pertama, baik dari segi jumlah unit usaha $(27,2 \%)$, jumlah tenaga kerja yang berhasil diserap $(31,0 \%)$ maupun nilai investasi yang ditanamkan $(34,3 \%)$. Produk unggulan Kabupaten Bantul antara lain mebel kayu, produk tekstil, kerajinan kayu, kerajinan pandan, kerajinan keramik, tas polyster, kerajinan bambu, kerajinan tanah liat, dan kerajinan batu. Produk industri kecil dari Bantul telah lama memasuki pasar domestik maupun luar negeri.

Memasuki tahun 2004, industri kerajinan di Bantul kian berkembang. Nilai produksi industri kecil di Bantul mencapai 439.588 juta setahun dengan nilai investasi industri sebesar Rp 264.718 juta. Realisasi ekspor sampai April 2004 mencapai US\$ 1,452 juta dengan volume ekspor 599.254 ribu. Orientasi ekspor mencakup 23 negara, antara lain Italia, Perancis, Amerika, Negaranegara Eropa, Timur Tengah dan Australia. Potensi industri kecil ini diperkirakan terus meningkat dalam tahun-tahun mendatang (Kompas, 2004)

Setiap jenis usaha pasti diharapkan bisa menghasilkan keuntungan, baik itu usaha besar maupun usaha kecil. Tingkat keuntungan suatu usaha merupakan pencerminan dari keberhasilan usaha suatu perusahaan. Semakin besar keuntungan berarti perusahaan tersebut akan mampu memenuhi kewajibannya dan lebih berpotensi untuk berkembang.

Usaha/industri kecil dan menengah di Kabupaten Bantul lebih potensial untuk dikembangkan karena akan mengurangi pengangguran dan akan meningkatkan pendapatan masyarakat dengan investasi yang jauh lebih sedikit dibandingkan usaha besar. Salah satu jenis industri kecil dan menengah di Kabupaten Bantul yang memberikan kontribusi kepada pengembangan usaha adalah industri batik kayu. Lokasi tepatnya adalah di Dusun Krebet Kecamatan Pajangan yang saat ini terdapat kurang lebih 40 unit usaha yang dapat menyerap sekitar 500 tenaga kerja.

Dari realitas tersebut diketahui bahwa usaha industri batik kayu di Dusun Krebet, Pajangan, Bantul mempunyai peran yang cukup penting dilihat dari sisi penyerapan tenaga kerja dan distribusi pendapatan masyarakat, sehingga dipandang perlu untuk lebih mengembangkan usaha tersebut agar dapat memberikan nilai tambah yang lebih besar bagi pembangunan daerah. Berdasarkan latar belakang di atas, penelitian ini bertujuan untuk mengetahui faktor apa yang paling signifikan menentukan tingkat keuntungan perajin serta melihat perbedaan keuntungan yang diperoleh perajin apabila dilihat dari aspek produksi, aspek pemasaran, serta aspek sosial dan ekonomi. Hasil penelitian ini diharapkan: 1) Sebagai masukan bagi pemerintah daerah Kabupaten Bantul dalam menentukan kebijakan mengenai kemajuan usaha industri kecil dan menengah khususnya usaha kerajinan batik kayu di Dusun Krebet, Sendangsari, Pajangan, Bantul. 2) Sebagai masukan bagi para perajin industri batik kayu dalam upaya meningkatkan pendapatannya. 3) Sebagai tambahan referensi bagi penelitian tentang industri kecil dan menengah. 


\section{TINJAUAN LITERATUR DAN PENGEMBANGAN HIPOTESIS}

\subsection{Pengertian dan Karaktristik Usaha Industri Kecil dan Menengah}

Pengertian usaha industri kecil dan menengah sangat beragam, tergantung instansi mana yang mendefinisikannya dengan sisi pandang yang berlainan. Misalnya Departemen Perindustrian dan Bank Indonesia berdasar nilai asetnya, Departemen Perdagangan berdasarkan pada modal kerjanya, Badan Pusat Statistik lebih mendasarkan pada jumlah tenaga kerjanya di mana dikategorikan usaha kecil menengah apabila jumlah tenaga kerjanya antara 5 sampai 99 orang. Pengertian Usaha Mikro, Kecil, dan Menengah dapat diringkas sebagai berikut (Harsoyo, 2005):

a. Usaha Mikro adalah usaha yang memiliki kekayaan bersih tidak lebih dari Rp 50 juta, omset penjualan maksimum Rp 250 juta per tahun, jumlah tenaga kerja 1-4 orang, dan plafon kredit maksimum Rp 50 juta.

b. Usaha Kecil adalah usaha yang memiliki kekayaan bersih di atas Rp 50 juta sampai dengan Rp 200 juta, omset penjualan maksimum Rp 1 milyar per tahun, jumlah tenaga kerja 5-19 orang, dan plafon kredit maksimum Rp 500 juta.

c. Usaha Menengah adalah usaha yang memiliki kekayaan bersih di atas Rp 200 juta sampai dengan maksimum Rp 10 milyar, jumlah tenaga kerja 20-99 orang, dan plafon kredit di atas Rp 500 juta sampai dengan Rp 5 milyar.

Karakteristik atau ciri-ciri usaha industri kecil menengah secara umum yaitu (Prawirokusumo, 2001):

a. Fleksibel dalam arti jika menghadapi hambatan dalam menjalankan usahanya akan berpindah ke usaha lain.

b. Permodalannya tidak selalu tergantung pada modal dari luar, mereka mampu berkembang dengan kekuatan modal sendiri.

c. Dalam hal pinjaman sanggup mengembalikan pinjaman dengan bunga yang cukup tinggi.

d. Merupakan sarana distributor barang dan jasa dalam rangka melayani kebutuhan masyarakat.

\subsection{Peranan Usaha Industri Kecil dan Menengah}

\section{Peranan Usaha Industri Kecil dan Menengah antara lain:}

a. Memiliki potensi yang besar dalam penyerapan tenaga kerja. Tiap unit investasi pada sektor UKM dapat menciptakan lebih banyak kesempatan kerja bila dibandingkan dengan investasi yang sama pada usaha besar maupun menengah. Pada tahun 2003, ternyata UKM menyerap 99,4\% dari seluruh tenaga kerja.

b. Memiliki kemampuan untuk memanfaatkan bahan baku lokal, memegang peranan utama dalam pengadaan produk dan jasa bagi masyarakat, dan secara langsung menunjang kegiatan usaha yang berskala lebih besar.

c. UKM relatif tidak memiliki utang dalam jumlah besar.

d. UKM memberikan sumbangan sebesar 58,30\% dari PDB nasional pada tahun 2003 , karena masalah yang dihadapi bangsa Indonesia saat ini adalah tingginya tingkat pengangguran.

e. Dapat menumbuhkan usaha di daerah, yang mampu menyerap tenaga kerja.

f. Akhir-akhir ini peran UKM diharapkan sebagai salah satu sumber peningkatan ekspor non migas.

\subsection{Keuntungan UKM}

Seperti halnya kegiatan bisnis pada umumnya, dalam menjalankan kegiatannya UKM juga perlu mengupayakan keuntungan yang memadai. Tingkat keuntungan suatu perusahaan merupakan pencerminan dari keberhasilan usaha sebuah perusahaan. Karena semakin besar 
keuntungan berarti perusahaan tersebut akan mampu memenuhi kewajibannya dan lebih berpotensi untuk berkembang. Dalam ilmu ekonomi pengertian keuntungan adalah pendapatan dikurangi biaya ( $\pi=\mathrm{TR}-\mathrm{TC}$ ), sehingga semakin tinggi $\pi$ maka kondisi perusahaan semakin baik. Dalam jangka pendek, untuk mencapai keuntungan yang maksimal, perusahaan akan mengusahakan biaya marginal sama dengan penerimaan marginal ( $M R=M C$ ). Dalam jangka panjang, biaya rata-rata akan sama dengan biaya marginal yang sama juga dengan harga ( $A C=$ $M C=P$ ) sehingga perusahaan hanya akan menikmati zero economic profit.

Tingkat keuntungan sangat ditentukan oleh faktor output dan input yang dipergunakan. Sedangkan tinggi rendahnya output dipengaruhi antara lain oleh volume produksi, pengalaman, perubahan institusi (Mc Connell, 1995). Dalam penelitian ini, faktor yang mempengaruhi keuntungan yaitu nilai produksi, umur usaha, dan umur pengusaha (perajin). Dengan demikian keuntungan usaha dapat diformulasikan menjadi:

Di mana:

$$
Y=f\left(X_{1}, X_{2}, X_{3}\right)
$$

$Y$ adalah tingkat keuntungan perajin

$\mathrm{X}_{1}$ adalah nilai produksi

$\mathrm{X}_{2}$ adalah umur usaha

$\mathrm{X}_{3}$ adalah umur perajin

Penelitian terdahulu Agung Zulianto (Zülianto, 2003) menganalisis faktor-faktor yang mempengaruhi tingkat keuntungan perajin, studi kasus pada usaha industri rotan di Kecamatan Gatak, Kabupaten Sukoharjo. Jumlah sampel yang diambil sebesar 40 dari 122 unit usaha yang ada di daerah tersebut. Teknik pengambilan sampel proportional random sampling. Hasil yang diperoleh adalah variabel nilai produksi akan berpengaruh secara positif dan signifikan terhadap keberhasilan industri rotan, sedangkan variabel independen yang lain tidak signifikan.

Lisa Daniels dan Donald C. Mead (Daniels dan Mead, 1998) menganalisis faktor-faktor yang mempengaruhi keuntungan perbulan dari usaha kecil dan menengah, lokasi penelitian di Kenya. Hasilnya terdapat beberapa variabel yang mempengaruhi keuntungan yaitu umur usaha, umur pengrajin, jumlah tenaga kerja, jenis kelamin, dan pendidikan, sedangkan variabel lokasi usaha, kredit, dan modal tidak berpengaruh.

Dientje Rumerung (Rumerung, 1992), meneliti usaha kerajinan rotan di Kotamadya Ambon. Hasil penelitian menunjukkan bahwa terdapat variabel-variabel yang mempengaruhi keberhasilan usaha (keuntungan) yaitu variabel biaya bahan, volume produksi, serta variabel harga jual per unit output. Sedangkan variabel yang paling dominan mempengaruhi keberhasilan adalah variabel volume produksi.

Berdasarkan tinjauan pustaka dan hasil penelitian sebelumnya maka hipotesis yang diajukan adalah: 1) Faktor nilai produksi, umur usaha, dan umur perajin secara bersama-sama mempengaruhi tingkat keuntungan perajin. 2) Variabel nilai produksi paling signifikan berpengaruh terhadap tingkat keuntungan pengrajin. 3) Ada perbedaan rata-rata keuntungan perajin batik kayu bila dilihat berdasarkan aspek produksi, aspek pemasaran, serta aspek sosial dan ekonomi.

\section{METODA PENELITIAN}

\subsection{Jenis Lokasi dan Waktu Penelitian}

Jenis penelitian yang digunakan dalam penelitian ini adalah studi kasus. Studi kasus adalah penelitian yang terperinci mengenai suatu obyek tertentu dan kesimpulan yang ditarik dari hasil penelitian hanya berlaku terhadap obyek yang diteliti dalam kurun waktu tertentu. 
Kesimpulan yang diperoleh tidak dapat digeneralisasikan terhadap obyek dan kurun waktu yang lain (Husein, 1992). Lokasi penelitian mengambil tempat di Dusun Krebet, Desa Sendangsari, Kecamatan Pajangan, Kabupaten Bantul yang terletak sekitar 9 km dari ibukota Kabupaten Bantul. Penelitian dilakukan pada bulan Agustus - September 2005.

\subsection{Populasi dan Sampel Penelitian}

Populasi dalam penelitian ini adalah seluruh unit usaha industri batik kayu di Dusun Krebet yaitu sejumlah 40 unit usaha. Sampel adalah sebagian dari populasi yang dipilih untuk diteliti. Dalam penelitian ini sampel yang digunakan adalah sebesar 30 unit usaha yang dipandang representatif. Teknik pengambilan sampel yang digunakan adalah Purposive Sampling, yaitu teknik pengambilan sampel dengan pertimbangan tertentu (Sugiyono, 2000). Responden yang dipilih adalah perajin yang telah menjalankan usaha lebih dari 1 tahun.

\subsection{Definisi Operasional Variabel}

Dalam rangka membatasi permasalahan dalam penelitian ini, maka diperlukan definisi operasional variabel yang dipergunakan, yaitu:

1. Keberhasilan usaha Indikator yang digunakan sebagai proksi keberhasilan usaha adalah tingkat keuntungan satu bulan yang diterima perajin (total penjualan - total biaya) dinyatakan dalam Rupiah.

2. Nilai Produksi

Variabel nilai produksi diambil sebagai proksi dari kuantitas produksi yang dihasilkan oleh perajin, sedangkan indikator yang digunakan adalah nilai total produksi (harga $\mathrm{x}$ kuantitas) yang dihasilkan oleh perajin selama satu bulan dan dinyatakan dalam Rupiah.

3. Umur Usaha

Umur usaha yang dimaksud adalah pengalaman perajin dalam menekuni usaha kerajinan batik kayu dan indikatornya adalah lamanya waktu yang telah dilalui perajin dihitung mulai menekuni usaha ini sampai dengan penelitian ini dilakukan yang dinyatakan dalam satuan tahun.

4. Umur Perajin

Indikatornya adalah usia perajin pada saat diadakan penelitian dan dinyatakan dalam satuan tahun.

5. Modal Usaha

Indikator modal usaha adalah seluruh modal baik modal kerja (pembelian bahan baku, bahan pembantu, tenaga kerja, dsb) maupun modal tetap (pembelian peralatan dan penyusutan) yang digunakan untuk menunjang usaha dan dinyatakan dalam satuan Rupiah.

6. Sumber Modal

Variabel ini menunjukkan dari mana para perajin mendapatkan modal usaha, terdapat dua alternatif yaitu modal pribadi dan pinjaman dari pihak luar.

7. Jumlah Tenaga Kerja

Variabel ini menunjukkan seluruh tenaga kerja yang terlibat langsung dalam kegiatan usaha, terdiri dari tenaga kerja yang diupah dan tidak diupah (keluarga) dinyatakan dalam satuan orang.

8. Curahan Jam Kerja

Diindikasikan dengan jumlah jam kerja per hari dikalikan jumlah hari kerja dalam satu bulan

9. Sistem Penjualan

Variabel ini berkaitan dengan metode perajin dalam menjual produknya pada konsumen apakah langsung ataukah melalui perantara.

10. Keanggotaan Koperasi 
Diindikasikan oleh keanggotaan perajin pada koperasi perajin yang berada di wilayah Dusun Krebet, Kecamatan Pajangan tersebut. Nilai 0 untuk perajin yang tidak/belum menjadi anggota koperasi dan nilai 1 untuk perajin yang telah menjadi anggota.

\subsection{Analisis Data}

\subsubsection{Regresi Linier Berganda (Multiple Linear Regression)}

Alat analisis ini digunakan untuk melihat pengaruh variabel-variabel yang menentukan tingkat keuntungan perajin secara bersama-sama. Keuntungan perajin sangat ditentukan oleh output. Tinggi rendahnya output dipengaruhi oleh nilai produksi, umur usaha, dan umur perajin (Connel, 1995). Penelitian ini melihat pengaruh nilai produksi, umur usaha, dan umur perajin terhadap tingkat keuntungan. Pengaruh umur usaha dan umur perajin tersebut melalui peningkatan produktivitas kemudian output meningkat. Dengan asumsi harga output tetap maka kenaikan output akan menaikkan keuntungan. Secara matematis kaitan antara variabel dependen dan independen dituliskan sebagai berikut:

Di mana:

$$
Y=f\left(X_{1}, X_{2}, X_{3}\right)
$$

$Y$ adalah tingkat keuntungan perajin (profit)

$\mathrm{X}_{1}$ adalah nilai produksi

$X_{2}$ adalah umur usaha

$\mathrm{X}_{3}$ adalah umur perajin

Jika ditulis dalam bentuk regresi linier berganda sebagai berikut (Gujarati, 1995):

Di mana:

$$
Y=b_{0}+b_{1} X_{1}+b_{2} X_{2}+b_{3} X_{3}+e
$$

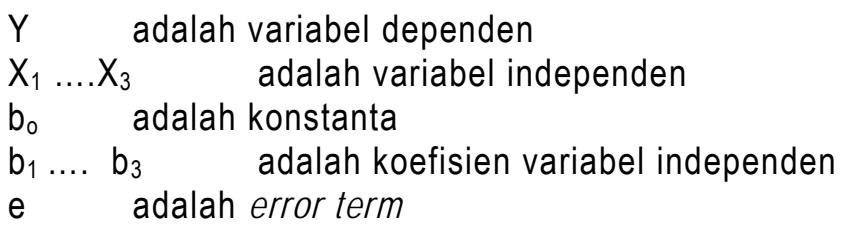

Untuk menguji signifikansi pengaruh variabel independen secara bersama-sama terhadap variabel dependen digunakan uji F. Sedangkan untuk menguji signifikansi pengaruh variabel independen secara parsial terhadap variabel dependen digunakan uji t.

\subsubsection{Uji Asumsi Klasik}

Uji asumsi klasik yang digunakan adalah uji multikolinearitas, uji autokorelasi, dan uji heteroskedastisitas. Uji multikolinearitas adalah hubungan eksak linier antar variabel independen dalam model. Konsekuensinya adalah signifikansi variabel menjadi tidak valid. Uji autokorelasi menunjukkan adanya hubungan antara residual pada satu pengamatan dengan pengamatan yang lain. Konsekuensinya adalah varian yang dihasilkan menjadi bias. Sedangkan uji heteroskedastisitas dimaksudkan untuk mengetahui apakah variasi residual absolut sama atau tidak sama untuk semua pengamatan. Apabila asumsi tidak terjadinya heteroskedastisitas ini tidak terpenuhi, maka penaksir menjadi tidak lagi efisien baik dalam sampel kecil maupun sampel besar dan estimasi koefisien menjadi kurang akurat (Gujarati, 1995).

\subsubsection{Uji Beda Rata-Rata Tingkat Keuntungan}

Pengujian beda rata-rata dimaksudkan untuk mengkuantitatifkan data-data kualitatif. Tujuannya adalah untuk melihat apakah ada perbedaan keuntungan antara kelompok perajin yang memiliki kualifikasi tertentu, yaitu: 
- Apabila dilihat dari aspek produksi yang meliputi lama berusaha, sumber permodalan, jumlah tenaga kerja, curahan jam kerja.

- Apabila dilihat dari aspek pemasaran yang meliputi sistem penjualan, pemasangan iklan

- Apabila dilihat dari aspek sosial dan ekonomi lainnya yang meliputi kualifikasi umur usaha, umur perajin, kepemilikan perijinan, jumlah tanggungan, keanggotaan koperasi. Alat analisis yang digunakan adalah Independent Sample t test (Santosa, 1999).

\section{HASIL ANALISIS DAN PEMBAHASAN}

\subsection{Gambaran Umum Lokasi Penelitian}

Dusun Krebet adalah bagian dari 18 pedukuhan yang ada di Desa Sendangsari, Kecamatan Pajangan, Bantul. Dusun yang dipromosikan Kabupaten Bantul sebagai desa wisata pada tahun 2002 ini mempunyai luas wilayah \pm 104 hektar dan berpenduduk 830 jiwa. Dari jumlah itu sebanyak 88 persen penduduk menjadi perajin kayu dan bekerja sebagai petani ladang tadah hujan. Dapat dikatakan, hampir tidak ada pemuda yang menganggur di Dusun Krebet karena terserap menjadi tenaga kerja pada industri kerajinan kayu.

Industri kerajinan kayu yang mulai ada tahun 1972, mula-mula hanya dijalani oleh 2-3 kepala keluarga, kemudian berkembang pesat sejak tahun 1990-an. Saat ini di Dusun Krebet tersebar kurang lebih 40 usaha kerajinan kayu yang dapat menyerap sekitar 400-an tenaga kerja lokal. Ciri utama dari hasil kerajinan kayu di Krebet yaitu terdapat motif dan pola batik yang digambar dipermukaannya. Kerajinan batik kayu yang paling terkenal adalah jenis wayang klithik. Selain itu juga dihasilkan topeng, loro blonyo, asbak, dakon, gantungan kunci, patung-patung hewan, berbagai peralatan rumah tangga, dan peralatan meubel bermotif batik.

Usaha kerajinan batik kayu yang selama ini berfungsi memenuhi kebutuhan sehari-hari, akhirnya berkembang menjadi usaha yang berorientasi ekspor. Hasil kerajinan tersebut dipasarkan dengan cara membuka showroom di sanggar, sebagian besar dijual ke Bali, juga di Jakarta, Surabaya, Yogya atau dijual melalui eksportir yang sebagian besar lewat Bali dan Jakarta. Akan tetapi setelah Bandara Adisucipto berubah status menjadi bandara internasional, eksportir bisa mengirim barang langsung dari Yogyakarta ke sejumlah trading house di Singapura atau Kuala Lumpur. Para perajin di Krebet mempunyai harapan dapat memasarkan produk secara langsung ke luar negeri, namun masih terkendala oleh lemahnya jaringan pemasaran. Meskipun demikian dengan dibangunnya Pasar Seni Gabusan Bantul, serta upaya sebagian perajin untuk mempromosikan kreativitas mereka lewat jaringan internet diharapkan dapat meningkatkan penjualan.

Kerajinan batik kayu di Dusun Krebet Desa Sendangsari, juga menjadi suguhan utama kepariwisataan desa setempat. Banyak wisatawan berkunjung ke Dusun Krebet untuk melihat secara langsung proses pembuatan batik kayu ataupun studi banding. Meskipun begitu, dusun ini masih memerlukan sejumlah prasarana pendukung kepariwisataan.

Dalam proses produksinya, perajin batik kayu biasanya menggunakan peralatan utama berupa mesin gergaji Jigsaw besar dan kecil, mesin bor besar dan kecil, mesin ampelas (grendha). Selain itu ditunjang dengan alat-alat lain seperti: pisau ukir, ampelas, canting untuk membatik, drum untuk merebus kayu yang sudah dibatik, kuas, kompor dan wajan kecil.

\subsection{Karakteristik Responden}

Keuntungan yang diperoleh seluruh unit usaha selama satu bulan berkisar antara Rp. 89.000,- sampai Rp. 79.296.000,-. Namun untuk tiap responden keuntungan tersebut sangat bervariasi. Data keuntungan perajin selengkapnya dapat dilihat pada tabel 3 berikut. 
Tabel 3

Keuntungan Perajin Batik Kayu di Dusun Krebet, 2005

\begin{tabular}{ccc}
\hline Keuntungan (000 Rp) & Jumlah Responden & Persentase \\
\hline$<2.000$ & 11 & 36,7 \\
$2.000-3.999,9$ & 4 & 13,3 \\
$4.000-5.999,9$ & 3 & 10 \\
$6.000-7.999,9$ & 2 & 6,7 \\
$8.000-9.999,9$ & 1 & 3,3 \\
$10.000-11.999,9$ & 0 & 0 \\
$\geq 12.000$ & 9 & 30 \\
J u m I a h & 30 & 100 \\
\hline
\end{tabular}

Sumber: data primer, diolah

Modal merupakan variabel penting dalam produksi kerajinan batik kayu di Dusun Krebet. Sumber modal bagi sebagian besar perajin (67\%) merupakan modal campuran yang berasal dari modal sendiri dan pinjaman. Sementara itu ada 10 perajin (33\%) yang murni menggunakan dana pribadi sebagai modal usahanya.

Besarnya modal yang digunakan oleh para perajin berkisar antara Rp 2 juta. sampai $R p$ 40 juta atau rata-rata Rp. 10 juta. Sedangkan lembaga yang biasa memberikan pinjaman modal bagi perajin adalah Bank Pemerintah (BRI), BPR, PT Taspen, Askrindo, tetapi ada juga perajin yang masih berhubungan dengan rentenir.

Pada Tabel 4 dapat dicermati data umur usaha para perajin batik kayu di Krebet. Sebagian besar $(80 \%)$ perajin menggeluti usaha kerajinan batik kayu belum genap 15 tahun. Hal ini wajar, mengingat usaha kerajinan batik kayu di Krebet mulai ada awal tahun 1970-an dan baru berkembang pesat di tahun 90 -an.

Tabel 4

Umur Usaha Kerajinan Batik Kayu di Dusun Krebet, 2005

\begin{tabular}{ccc}
\hline Umur Usaha (thn) & Jumlah Responden & Persentase \\
\hline $0-4$ & 7 & 23,3 \\
$5-9$ & 8 & 26,7 \\
$10-14$ & 9 & 30 \\
$15-19$ & 3 & 10 \\
$20-24$ & 1 & 3,3 \\
$25-29$ & 1 & 3,3 \\
$30-34$ & 0 & 0 \\
$35-39$ & 1 & 3,3 \\
J u m I a h & 30 & 100 \\
\hline
\end{tabular}

Sumber: data primer, diolah

Tenaga kerja yang dipekerjakan setiap perajin batik kayu di Dusun Krebet bervariasi antara 1 sampai 50-an orang. Secara keseluruhan tenaga kerja yang terserap pada industri kerajinan ini sebanyak 470 orang dan sebagian besar berasal dari warga desa setempat. Ada juga perajin yang menggunakan tenaga kerja dari daerah lain karena membuka sanggar/pos di Klaten.

Banyak perajin yang juga mempekerjakan anggota keluarganya, namun tetap diupah. Hanya sebagian kecil saja yang tidak memberikan upah kepada istri atau anaknya yang ikut bekerja. Para perajin pada umumnya bekerja selama 6 hari kerja per minggu dengan rata-rata 8 
jam kerja sehari. Sistem pengupahan sebagian besar dilakukan secara borongan, namun ada juga tenaga kerja yang diupah secara mingguan atau harian.

Tabel 5

Jumlah Tenaga Kerja dalam Industri Kerajinan Batik Kayu di Dusun Krebet, 2005

\begin{tabular}{ccc}
\hline $\begin{array}{c}\text { Jumlah tenaga kerja } \\
\text { (orang) }\end{array}$ & Jumlah Responden & Persentase \\
\hline $1-10$ & 19 & 63,3 \\
$11-20$ & 4 & 13,3 \\
$21-30$ & 3 & 10 \\
$31-40$ & 1 & 3,3 \\
$41-50$ & 1 & 3,3 \\
$>50$ & 2 & 6,7 \\
J u m I a h & 30 & 100 \\
\hline
\end{tabular}

Sumber: data primer, diolah

Pemasaran merupakan kunci pokok dalam suatu usaha sehingga sangat berpengaruh terhadap tingkat keberhasilan para perajin. Hasil penelitian menunjukkan bahwa dalam memasarkan produksinya, ada $43 \%$ perajin yang murni melakukan penjualan langsung pada konsumen, sementara $57 \%$ perajin selain melakukan penjualan langsung kepada konsumen juga melalui perantara.

Dari 30 perajin yang dijadikan reseponden, terdapat 10 perajin (33\%) yang sudah mulai merambah pasar luar negeri melalui jasa perantara/eksportir, sedangkan 20 perajin baru mampu menjangkau pasar dalam negeri. Para perajin yang produknya telah memasuki pasar luar negeri pada dasarnya mempunyai harapan dapat memasarkan secara langsung ke mancanegara. Namun sejauh ini masih terkendala oleh lemahnya jaringan pemasaran, sehingga yang dapat dilakukan adalah penjualan melalui perantara para eksportir.

Berdasarkan jawaban responden diketahui bahwa hanya ada 2 perajin yang menyatakan sudah memanfaatkan kapasitas produksi secara penuh (100\%). Sedangkan 28 perajin lainnya belum memanfaatkan kapasitas produksi secara penuh atau rata-rata baru $50 \%-75 \%$. Hal itu disebabkan oleh adanya berbagai hambatan usaha.

Hambatan yang paling banyak dihadapi oleh perajin adalah masalah permodalan, kemudian baru hambatan-hambatan lainnya seperti: kesulitan bahan baku, kurangnya tenaga ahli, dan kurangnya permintaan. Kesulitan atau keengganan perajin dalam mencari tambahan modal sebagian besar disebabkan oleh masalah prosedur yang sulit, tingginya tingkat bunga, dan masalah agunan/jaminan yang tidak dapat dipenuhi. Selain itu para perajin juga mengalami hambatan pemasaran seperti kurangnya promosi/periklanan, adanya persaingan harga, dan permintaan yang tidak kontinyu.

Untuk mengatasi hambatan tersebut sudah selayaknya ditingkatkan kerjasama yang baik antara pihak Pemerintah khususnya dan lembaga swasta dengan para perajin. Pemerintah perlu memberikan dukungan baik berupa dana, fasilitas, maupun pendidikan kepada para perajin. Demikian juga dari pihak perajin harus terbuka kepada Pemerintah dan merespon dengan positif setiap itikad baik dari Pemerintah. Berdasarkan data yang diperoleh, baru $50 \%$ perajin (15 responden) yang sudah menikmati bantuan dari lembaga pemerintahan seperti Deperindag, Pemda Bantul, Dinas Perindustrian, Dinas Sosial, Dikti, BUMN, Depnaker dan UGM. Bantuan yang diterima dalam berbagai bentuk antara lain: bantuan keuangan, peralatan/teknis, penyuluhan, fasilitas pameran.

Sebagian besar perajin (24 responden) sudah tergabung dalam keanggotaan koperasi. Perajin yang belum mengikuti koperasi ada 6 responden, alasannya antara lain: belum berminat 
atau malas mengikuti, merasa tidak ada manfaatnya, belum mampu ikut karena terlalu mikronya usaha (pesanan barang belum tentu ada).

Dari 30 perajin yang dijadikan responden baru 14 yang sudah mempunyai ijin usaha, sedangkan 16 usaha kerajinan belum berijin. Alasan yang dikemukakan perajin dapat dicermati pada tabel berikut:

Tabel 6

Alasan Perajin Batik Kayu di Dusun Krebet Belum Mengurus Perijinan

\begin{tabular}{lcc}
\hline \multicolumn{1}{c}{ Alasan } & Jumlah Responden & Persentase \\
\hline Usaha belum stabil & 6 & 37,4 \\
Tidak penting / belum membutuhkan/ & 4 & 25 \\
merupakan usaha sambilan & & \\
Malas mengurus & 3 & 18,7 \\
Kekurangan biaya & 1 & 6,3 \\
Tidak paham prosedur & 1 & 6,3 \\
Baru merencanakan & 1 & 6,3 \\
J u m I a h & 16 & 100 \\
\hline Sumber: data primer, diolah & &
\end{tabular}

Besarnya tanggung jawab perajin dapat didekati dari berapa jumlah tanggungan keluarga. Dari seluruh perajin yang dijadikan reseponden, jumlah tanggungan bervariasi antara 0 - 7 orang, tetapi secara rata-rata jumlah tanggungan 2 orang. Ada satu orang perajin yang tidak mempunyai tanggungan karena memang yang bersangkutan belum berkeluarga dan hanya menghidupi dirinya sendiri.

Umur para perajin batik kayu di Dusun Krebet sangat beragam antara 18 - 55 tahun. Kalau melihat rata-rata umur perajin yang relatif muda usia, hal ini dimungkinkan karena kerajinan batik kayu di Krebet baru mulai marak tahun 90an. Selain itu, dalam usaha ini dibutuhkan suatu kreativitas seni, ketelitian dan inovasi pada bentuk dan desain produk, sehingga lebih menantang untuk dikembangkan oleh para perajin yang usianya belum terlalu tua.

Tabel 7

Umur Perajin Batik Kayu di Dusun Krebet, 2005

\begin{tabular}{ccc}
\hline Umur Perajin (thn) & Jumlah Responden & Persentase \\
\hline $18-27$ & 4 & 13,3 \\
$28-37$ & 15 & 50 \\
$38-47$ & 10 & 33,4 \\
$48-57$ & 1 & 3,3 \\
J u m I a h & 30 & 100 \\
\hline
\end{tabular}

Sumber: data primer, diolah

\subsection{Hasil Analisis Regresi Linier Berganda}

Untuk mengetahui pengaruh variabel independen terhadap variabel dependen secara bersama-sama digunakan persamaan regresi linier berganda. Dengan menggunakan program SPSS versi 13 diperoleh hasil sebagai berikut:

$$
\begin{gathered}
\text { LPR }=\begin{array}{ccc}
-1,674+0,950 \text { LNP } & +0,114 \text { LUU }+0,282 \text { LUP } \\
(-0,503) \quad(8,299) & (0,374) & (0,267) \\
R^{2}=0,816 \text { F-Stat. }=29,469 & \text { D-W test }=1,861
\end{array}
\end{gathered}
$$

Ket: angka dalam kurung adalah nilai thitung 
Dari persamaan di atas diketahui bahwa koefisien regresi untuk variabel nilai produksi, umur usaha, dan umur perajin adalah positif sehingga apabila ada penambahan satu persen dari masingmasing variabel nilai produksi, umur usaha, dan umur perajin akan menyebabkan kenaikan tingkat keuntungan (profit) sebesar 0,950; 0,114; 0,282 persen ceteris paribus.

\subsubsection{Pengujian secara Statistik}

\section{a. Pengujian secara simultan}

Untuk menguji signifikansi pengaruh variabel independen (nilai produksi, umur usaha, dan umur perajin) secara bersama-sama terhadap variabel dependen (tingkat keuntungan perajin) digunakan uji F. Dengan menggunakan tingkat keyakinan 95\% dan derajat kebebasan pembilang 3 dan derajat kebebasan penyebut 26 maka diperoleh nilai $\mathrm{F}$ tabel sebesar 2,89. Dari hasil perhitungan program SPSS diperoleh nilai $F$ hitung sebesar 29,469 . Oleh karena nilai $\mathrm{F}$ hitung $>\mathrm{F}$ tabel maka Ho ditolak artinya variabel independen (nilai produksi, umur usaha, dan umur perajin) secara bersama-sama berpengaruh signifikan terhadap variabel dependen (tingkat keuntungan perajin).

Dilihat dari nilai determinasi $R^{2}$ menunjukkan angka 0,816 . Hal ini berarti bahwa variasi perubahan keuntungan sebesar 81,6 persen ditentukan bersama-sama oleh variabel nilai produksi, umur usaha, dan umur perajin, sedangkan sisanya (18,4 persen) ditentukan oleh variabel lain di luar model.

\section{b. Pengujian secara parsial}

Untuk menguji signifikansi pengaruh variabel independen (nilai produksi, umur usaha, dan umur perajin) secara parsial terhadap variabel dependen (tingkat keuntungan perajin) digunakan uji t. Dengan menggunakan tingkat keyakinan $95 \%$ dan derajat kebebasan sebesar 28 maka diperoleh nilai $t$ tabel sebesar 2,048. Dari hasil persamaan regresi linier berganda diketahui bahwa nilai t hitung untuk variabel nilai produksi adalah sebesar 8,299 dan t tabel adalah 2,048 maka Ho ditolak. Hal ini menunjukkan bahwa variabel nilai produksi berpengaruh secara signifikan terhadap tingkat keuntungan perajin, artinya apabila nilai produksi naik sebesar satu persen maka tingkat keuntungan perajin akan meningkat sebesar 0,95 persen, ceteris paribus.

Untuk variabel umur usaha diperoleh nilai $t$ hitung sebesar 0,374 berarti nilai $t$ hitung $<t$ tabel maka artinya umur usaha tidak berpengaruh secara signifikan terhadap tingkat keuntungan. Sedangkan nilai thitung variabel umur perajin adalah sebesar 0,267 maka $t$ hitung $<t$ tabel artinya variabel umur perajin tidak berpengaruh secara signifikan terhadap tingkat keuntungan.

Jadi dari persamaan di atas diketahui bahwa faktor yang paling signifikan menentukan tingkat keuntungan perajin adalah variabel $X_{1}$ atau nilai produksi. Hal ini dapat dilihat dari nilai t hitung $(8,299)$ yang lebih besar dari t tabel $(2,048)$. Sedangkan variabel yang lain diketahui tidak berpengaruh secara signifikan. Dari persamaan tersebut diketahui juga bahwa pengaruh nilai produksi terhadap tingkat keuntungan adalah positif artinya semakin tinggi/besar nilai produksi maka semakin besar pula tingkat keuntungan perajin.

Tingkat keuntungan perajin yang merupakan proksi keberhasilan usaha perajin batik kayu di Dusun Krebet sangat dipengaruhi oleh nilai produksi yang juga merupakan proksi total produksi. Sebanyak 15 perajin (50 \%) menyatakan bahwa produksi yang mereka lakukan murni berdasarkan pesanan konsumen, sedangkan $50 \%$ perajin memproduksi barang tujuannya untuk memenuhi kebutuhan pasar dan berdasarkan pesanan konsumen. Karena sebagian besar produksi berdasarkan pesanan, maka desain maupun corak produk lebih sering sudah ditentukan oleh pemesan, sehingga para perajin kurang tertantang untuk memikirkan inovasi dan pengembangan model/corak produk yang baru. Kemungkinan hal inilah yang menyebabkan umur usaha dan umur perajin tidak berpengaruh secara signifikan terhadap tingkat keuntungan perajin. Selain itu dari data ditemukan bahwa pekerjaan sebagai perajin batik kayu merupakan pekerjaan utama bagi 26 perajin $(87 \%)$, sehingga mereka kurang berani berspekulasi untuk menciptakan inovasi baru. 


\subsection{Hasil Uji Asumsi Klasik}

\subsubsection{Uji Multikolinearitas}

Multikolinearitas adalah hubungan eksak linier antar variabel independen dalam model. Konsekuensinya adalah invalidnya signifikansi variabel. Dari nilai Variance Inflation Factor (VIF) diketahui bahwa nilai untuk tiap-tiap variabel bebas (nilai produksi, umur usaha, dan umur perajin) lebih kecil daripada 5. Pada umumnya jika VIF lebih besar dari 5, maka variabel tersebut mempunyai persoalan multikolinearitas dengan variabel bebas lainnya. Jadi dalam persamaan tersebut tidak terdapat multikolinearitas.

\subsubsection{Uji Autokorelasi}

Autokorelasi adalah adanya hubungan antara residual pada satu pengamatan dengan pengamatan yang lain. Konsekuensinya adalah varian yang dihasilkan menjadi bias yaitu lebih kecil dari yang sebenarnya sehingga nilai $\mathrm{R}^{2}$ dan $\mathrm{F}$ statatistiknya cenderung overestimated. Dari perhitungan diketahui bahwa nilai DW (Durbin Watson) hitung adalah sebesar 1,861. Angka tersebut berada di daerah tidak ada autokorelasi. Jadi pada persamaan regresi tersebut tidak terdapat autokorelasi (lihat tabel 8).

Tabel 8

Tabel Autokorelasi

\begin{tabular}{cc}
\hline Nilai Batas & Keterangan \\
\hline$<1,14$ & Autokorelasi Posistif \\
$1,14-1,74$ & Ragu-ragu \\
$1,75-2,25$ & Tidak ada Autokorelasi \\
$2,26-2,86$ & Ragu-ragu \\
$>2,86$ & Autokorelasi Negatif \\
\hline
\end{tabular}

Sumber: Gujarati, 1995: 422

\subsubsection{Uji Heteroskedastisitas}

Heteroskedastisitas adalah adanya variasi residual absolut yang tidak sama untuk semua pengamatan. Jika hal ini terjadi maka penaksir menjadi tidak lagi efisien baik dalam sampel kecil maupun sampel besar dan estimasi koefisien menjadi kurang akurat (Gujarati, 1995). Pendekatan yang digunakan untuk mendeteksi ada tidaknya heteroskedastisitas adalah rank korelasi dari Spearman (Gujarati, 1995). Dari perhitungan diperoleh hasil sebagai berikut:

Tabel 9

Hasil Uji Heteroskedastisitas

\begin{tabular}{ccccc}
\hline Keterangan & Signifikansi & Alpha & Kondisi & Simpulan \\
\hline LNP - RESNP & 0,081 & 0,05 & Sig $>$ Alpha & Homoskedastis \\
LUU - RESUU & 0,424 & 0,05 & Sig > Alpha & Homoskedastis \\
LUP - RESUP & 0,680 & 0,05 & Sig > Alpha & Homoskedastis \\
\hline
\end{tabular}

Sumber: Data yang diolah

Tabel 9 di atas menunjukkan bahwa residual absolut mempunyai varian yang sama untuk semua pengamatan. Jadi pada persamaan regresi tersebut tidak terdapat heteroskedastisitas.

\subsection{Hasil Uji Beda Rata-rata Tingkat Keuntungan}

\subsubsection{Berdasarkan Aspek Produksi}

Dalam penelitian ini, aspek produksi meliputi sumber modal, lama berusaha, jumlah tenaga kerja, dan curahan jam kerja. Hasil uji beda rata-rata dengan menggunakan uji independent sample t test diperoleh hasil sebagai berikut: 
Tabel 10

Hasil Uji Beda Rata-Rata Keuntungan Berdasarkan Aspek Produksi

\begin{tabular}{lcl}
\hline \multicolumn{1}{c}{ Kriteria } & Signfikansi t & \multicolumn{1}{c}{ Keterangan } \\
\hline Sumber Modal & 0,011 & Ada perbedaan yang signifikan \\
Lama Berusaha & 0.138 & Tidak ada perbedaan yang signifikan \\
Jumlah Tenaga Kerja & 0,006 & Ada perbedaan yang signifikan \\
Curahan Jam Kerja & 0,507 & Tidak ada perbedaan yang signifikan \\
\hline
\end{tabular}

Sumber: Data yang diolah

Dari tabel 10 di atas diketahui bahwa ada perbedaan rata-rata keuntungan yang signifikan pada kelompok perajin berdasarkan sumber modal dan jumlah tenaga kerja. Sumber modal dibedakan yaitu sumber modal pribadi dan modal pinjaman, dan kelompok perajin berdasarkan tenaga kerja dibedakan kelompok perajin yang menggunakan tenaga kerja $<14$ orang dan $\geq 14$ orang. Untuk kelompok perajin berdasarkan lama berusaha dibedakan $\geq 10$ tahun dan $<10$ tahun. Sedangkan kelompok perajin berdasarkan curahan jam kerja dibedakan < 190 jam dan $\geq 190$ jam per bulan. Dari hasil penelitian, tidak ada perbedaan rata-rata keuntungan yang signifikan antara kelompok perajin berdasarkan lama berusaha dan curahan jam kerja.

\subsubsection{Berdasarkan Aspek Pemasaran}

Pengujian berdasarkan aspek pemasaran yang meliputi sistem penjualan dan pemasangan iklan. Hasilnya sebagai berikut:

Tabel 11

Hasil Uji Beda Rata-Rata Keuntungan Berdasarkan Aspek Pemasaran

\begin{tabular}{ccc}
\hline Kriteria & Signfikansi & Keterangan \\
\hline Sistem Penjualan & 0,069 & Tidak ada perbedaan yang signifikan \\
Pemasangan Iklan & 0,059 & Tidak ada perbedaan yang signifikan \\
\hline Sumber: Data yang diolah & &
\end{tabular}

Sistem penjualan perajin dibedakan sistem penjualan langsung/pembeli datang sendiri dan sistem penjualan melalui perantara. Dari hasil perhitungan diketahui bahwa tidak ada perbedaan keuntungan rata-rata antara kedua kelompok tersebut. Demikian pula untuk kelompok perajin yang memasang iklan maupun yang tidak memasang iklan tidak ada perbedaan rata-rata keuntungan. Hal ini disebabkan karena promosi yang dilakukan melalui periklanan masih terlalu sederhana dan cakupannya belum terlalu luas.

\subsubsection{Berdasarkan Aspek Sosial Ekonomi}

Pengujian berdasarkan aspek sosial ekonomi meliputi keanggotaan koperasi, ijin usaha, jumlah tanggungan, dan umur perajin. Hasilnya sebagai berikut:

Tabel 12

Hasil Uji Beda Rata-Rata Keuntungan Berdasarkan Aspek Sosial Ekonomi

\begin{tabular}{lcl}
\hline \multicolumn{1}{c}{ Kriteria } & Signfikansi t & \multicolumn{1}{c}{ Keterangan } \\
\hline Keanggotaan Koperasi & 0,426 & Tidak ada perbedaan yang signifikan \\
ljin Usaha & 0,033 & Ada perbedaan yang signifikan \\
Jumlah Tanggungan & 0,820 & Tidak ada perbedaan yang signifikan \\
Umur Perajin & 0,669 & Tidak ada perbedaan yang signifikan \\
\hline
\end{tabular}

Sumber: Data yang diolah 
Dari tabel tersebut terlihat bahwa terdapat perbedaan rata-rata keuntungan yang signifikan antara kelompok perajin yang telah berijin usaha dan yang tidak/belum berijin usaha. Bagi usaha kerajinan yang telah mempunyai ijin, biasanya mempunyai omzet produksi yang tinggi dan berani menerima pesanan dalam jumlah besar. Pembeli juga lebih percaya kepada usaha yang telah berijin, karena keberlangsungan usaha lebih terjamin. Apabila dilihat dari keanggotaan koperasi tidak ada perbedaan antara perajin yang sudah menjadi anggota koperasi ataupun yang tidak. Berdasarkan jumlah tanggungan, tidak ada perbedaan rata-rata keuntungan yang signifikan antara perajin yang memiliki tanggungan sedikit ( $<3$ orang) atau banyak ( $\geq 3$ orang). Demikian pula tidak ada perbedaan rata-rata keuntungan antara perajin yang berumur kurang dari 35 tahun dan yang berumur 35 tahun ke atas.

\section{PENUTUP}

Berdasarkan hasil analisis data dan pembahasan yang telah dilakukan terhadap usaha industri kerajinan batik kayu di Dusun Krebet, Sendangsari, Pajangan, Bantul dapat ditarik kesimpulan sebagai berikut: 1) Variabel nilai produksi merupakan variabel yang paling signifikan menentukan tingkat keuntungan perajin yang merupakan proksi keberhasilan usaha masyarakat Dusun Krebet, Pajangan, Bantul. 2) Berdasarkan aspek produksi, diketahui bahwa ada perbedaan rata-rata keuntungan yang signifikan pada kelompok perajin berdasarkan sumber modal dan jumlah tenaga kerja. Sedangkan pada kelompok perajin berdasarkan lama berusaha dan curahan jam kerja tidak ada perbedaan rata-rata keuntungan yang signifikan. 3) Dari aspek pemasaran, diketahui bahwa tidak ada perbedaan keuntungan rata-rata antara perajin yang melakukan penjualan langsung maupun yang melalui perantara dan juga tidak ada perbedaan rata-rata keuntungan yang signifikan antara perajin yang memasang iklan maupun yang tidak memasang iklan. 4) Sedangkan dari aspek sosial ekonomi, diketahui bahwa terdapat perbedaan rata-rata keuntungan yang signifikan antara kelompok perajin yang telah berijin usaha dan yang tidak/belum berijin usaha. Apabila dilihat dari keanggotaan koperasi, jumlah tanggungan, dan umur perajin tidak ada perbedaan rata-rata keuntungan yang signifikan.

Hasil penelitian menunjukkan bahwa nilai produksi adalah variabel yang paling menentukan tingkat keuntungan perajin yang merupakan proksi dari keberhasilan usaha. Dengan semakin berhasilnya usaha berarti tingkat pendapatan perajin akan meningkat. Oleh karena itu sebaiknya setiap perajin berusaha meningkatkan produksinya.

Agar produksi dapat dilaksanakan secara optimal, perajin harus mengusahakan tambahan modal. Apabila modal sendiri dirasa kurang mencukupi, perlu diupayakan mengajukan pinjaman dari Bank, Lembaga Keuangan Bukan Bank, ataupun Koperasi. Selain itu, peningkatan produksi perlu didukung dengan jumlah tenaga kerja yang cukup serta ketrampilan yang memadai sehingga keuntungan perajin meningkat dan taraf hiduppun meningkat.

Untuk meningkatkan penjualan, para perajin perlu memperhatikan aspek pemasaran. Pemasaran produk secara langsung ataupun lewat perantara sebaiknya dioptimalkan. Kerja sama dengan eksportir swasta, maupun dukungan berbagai lembaga terkait seperti Pemda, Deperindag dan dinas kepariwisataan diharapkan dapat memperkuat jaringan pemasaran dalam negeri dan luar negeri.

Upaya sebagian kecil perajin yang sudah mempromosikan kreativitas mereka lewat jaringan internet perlu diikuti oleh perajin yang lain. Dalam hal ini perajin dapat bekerja sama dalam paguyuban untuk mengusahakan bantuan dari pemerintah ataupun lembaga-lembaga swasta yang concern terhadap perkembangan UKM agar memberikan dukungan dalam bentuk fasilitas, pelatihan Teknologi Informasi (TI) ataupun pendampingan. Dengan demikian diharapkan cakupan promosi lebih luas dan efektif sehingga usaha para perajin dapat lebih berkembang.

Para perajin yang belum mempunyai ijin usaha, sedapat mungkin segera mengurusnya. Karena bagi usaha kerajinan yang telah berijin, biasanya mempunyai omzet produksi yang tinggi dan berani menerima pesanan dalam jumlah besar. Dengan legalitas usaha, pembeli akan lebih percaya karena keberlangsungan usaha lebih terjamin. 
Dari segi keanggotaan koperasi, kiranya perlu bagi perajin yang belum menjadi anggota koperasi berusaha bergabung menjadi anggota. Karena mengikuti koperasi banyak sekali manfaatnya, antara lain, mendapatkan informasi mengenai berbagai bantuan dari lembaga terkait, memperoleh informasi perkembangan pasar dari sesama perajin, memperoleh tambahan modal, tercipta jalinan relasi antar perajin dan akhirnya bisa diperoleh order pengerjaan barang. Dengan demikian secara keseluruhan perajin batik kayu di Dusun Krebet bisa berhasil dan akan memberi dampak positif pula terhadap peningkatan pendapatan masyarakat Dusun Krebet.

\section{DAFTAR PUSTAKA}

Daniels, Lisa and C. Mead, Donald (1998), "The Contribution of Small Enterprises to Household and National Income in Kenya", Economic Development and Cultural Change

Desembriarto, D. dan Hg. Suseno T.W. (2004), "Analisis Potensi dan Keberlanjutan UKM Kerajinan di DIY. Studi Kasus: Sentra Industri Gerabah Pundong”, Artikel Seminar Hasil Penelitian FE USD.

Gujarati, Damodar (1995), Basic Econometrics, Singapore: Mc Graw Hill, Inc.

Harsoyo (2005), "Peranan Bank dalam Mengembangkan Usaha Mikro, Kecil, dan Menengah (UMKM)", Makalah disampaikan pada Seminar Regional dalam rangka Dies Natalis FE Universitas Sanata Dharma XII, 16 April.

Kuncoro, Mudrajad (1997), Ekonomi Pembangunan: Teori, Masalah, dan Kebijakan, Yogyakarta: AMP YKPN.

R. Mc Connell Campbell and I. Brue Stanley (1995), Contemporary Labor Economics, Singapore: Mc Graw Hill Inc

Prawirokusumo Suharto (2001), Ekonomi Rakyat (Konsep, Kebijakan, dan Strategi), Yogyakarta: BPFE.

Rumerung, Dientje (1992), "Analisis Tingkat Keberhasilan Usaha Industri Kecil Kerajinan Rotan di Maluku (Suatu Studi Kasus di Kotamadya Ambon)", Tesis S2 (tidak dipublikasikan)

Santosa, Singgih (1999), SPSS: Mengolah Data Statistik Secara Profesional, Jakarta: PT. Elex Media Komputindo

Sartika, Tiktik \& Rachman (2002), Ekonomi Skala Kecil/Menengah \& Koperasi, Jakarta, Ghalia Indonesia.

Sugiyono (2000), Metode Penelitian Bisnis, Bandung: Alfabeta

Departemen Koperasi dan UKM (2004), Statistik Usaha Kecil dan Menengah, Jakarta.

Tambunan, Tulus T.H. (2002), Usaha Kecil dan Menengah di Indonesia- Beberapa Isu Penting, Jakarta: Penerbit Salemba Empat.

UPT Sentra Kerajinan Keramik (2002), Sekilas Tentang Sentra Keramik Kasongan Bangunjiwo, Kasihan, Kabupaten Bantul 
www. Bantul.go.id: Kecamatan Pajangan, 19 Januari 2006

www. Kompas.co.id: Kayu-kayu Pahat dari Bantul tanggal 29 Mei 2004

Zulianto, Agung (2003), "Kontribusi Industri Kecil dan Menengah terhadap Peningkatan Pendapatan Masyarakat", Tesis S2, (tidak dipublikasikan) 